GLOBAL WATER PATHOGEN PROJECT

PART FOUR. MANAGEMENT OF RISK FROM EXCRETA AND WASTEWATER

\title{
PRELIMINARY TREATMENT AND PRIMARY SEDIMENTATION
}

Stewart Oakley

California State University, Chico

Chico, United States 


\section{Copyright:}

\section{cc) (i) (2) \\ BY SA}

This publication is available in Open Access under the Attribution-ShareAlike 3.0 IGO (CC-BY-SA 3.0 IGO) license (http://creativecommons.org/licenses/by-sa/3.0/igo). By using the content of this publication, the users accept to be bound by the terms of use of the UNESCO Open Access Repository (http://www.unesco.org/openaccess/terms-use-ccbysa-en).

\section{Disclaimer:}

The designations employed and the presentation of material throughout this publication do not imply the expression of any opinion whatsoever on the part of UNESCO concerning the legal status of any country, territory, city or area or of its authorities, or concerning the delimitation of its frontiers or boundaries. The ideas and opinions expressed in this publication are those of the authors; they are not necessarily those of UNESCO and do not commit the Organization.

\section{Citation:}

Oakley, S. (2018). Preliminary Treatment and Primary Settling. In: J.B. Rose and B. Jiménez-Cisneros (eds), Water and Sanitation for the 21st Century: Health and Microbiological Aspects of Excreta and Wastewater Management (Global Water Pathogen Project). (J.R. Mihelcic and M.E. Verbyla (eds), Part 4: Management Of Risk from Excreta and Wastewater - Section: Sanitation System Technologies, Pathogen Reduction in Sewered System Technologies), Michigan State University, E. Lansing, MI, UNESCO.

https://doi.org/10.14321/waterpathogens.60

Acknowledgements: K.R.L. Young, Project Design editor; Website Design: Agroknow (http://www.agroknow.com)

Last published: July 24, 2018 


\section{Summary}

Preliminary treatment is used to remove screenings and grit that enters a wastewater treatment plant from a sewered system. Preliminary treatment will have little effect on pathogens in the liquid wastestream. Primary treatment (also called primary sedimentation) is a sanitation technology that removes suspended solids and floating organic material (called scum) to reduce the suspended solids load for subsequent treatment processes. The removal of pathogens during primary treatment is not high; therefore, downstream treatment will require further pathogen removal technologies to meet discharge or reuse guidelines. It is not expected that discrete pathogens and indicator organisms are removed by settling during conventional primary treatment. However, they may be removed when attached to particles. In ordinary primary sedimentation systems that are properly designed and operated, the reduction of all types of pathogens and fecal indicators can be expected to be between 0 and $1 \log _{10}$ units. With chemically-enhanced primary treatment and advanced primary treatment (also referred to as high-rate clarification) processes, helminth egg removal can be 1 to 3 $\log _{10}$ and virus, bacteria, and protozoa removal can be from 1 to $2 \log _{10}$. Screenings, grit, and sludge will contain high concentrations of pathogens and must be safely treated and/or disposed to protect public health.

\subsection{Preliminary Treatment: Bar Screens and Grit Chambers}

\subsection{Brief Technology Description}

Preliminary treatment is the removal of untreatable solids that first enter a wastewater treatment plant from the sewer and is comprised of the following two processes (Mara, 2003; Metcalf \&Eddy/AECOM, 2014):

Screening: The removal of floatable or suspended coarse solids in raw wastewater, which includes rags, paper, plastic, rubber, and vegetable matter (Clay et al., 1996). Bar screens are the most commonly used screening devices, with a typical spacing between bars of 15 to $25 \mathrm{~mm}$ (Mara, 2003). Bar screens are cleaned manually in small wastewater treatment plants and mechanically in large ones.

Grit removal: The gravity separation of heavy small solids with a specific gravity greater than putrescible organic matter (e.g., sand, gravel, coffee grounds). Grit is removed in grit chambers, which can be operated manually in small plants or be mechanized in larger plants.

Screenings and grit, if not removed at the beginning of a wastewater treatment plant, can impair downstream treatment processes and damage equipment (e.g., pumps) (Metcalf and Eddy/AECOM, 2014). Figure 1 shows where preliminary treatment is used within the sanitation service chain. Figures 2 through 5 show examples of manual and mechanized preliminary treatment systems in operation.

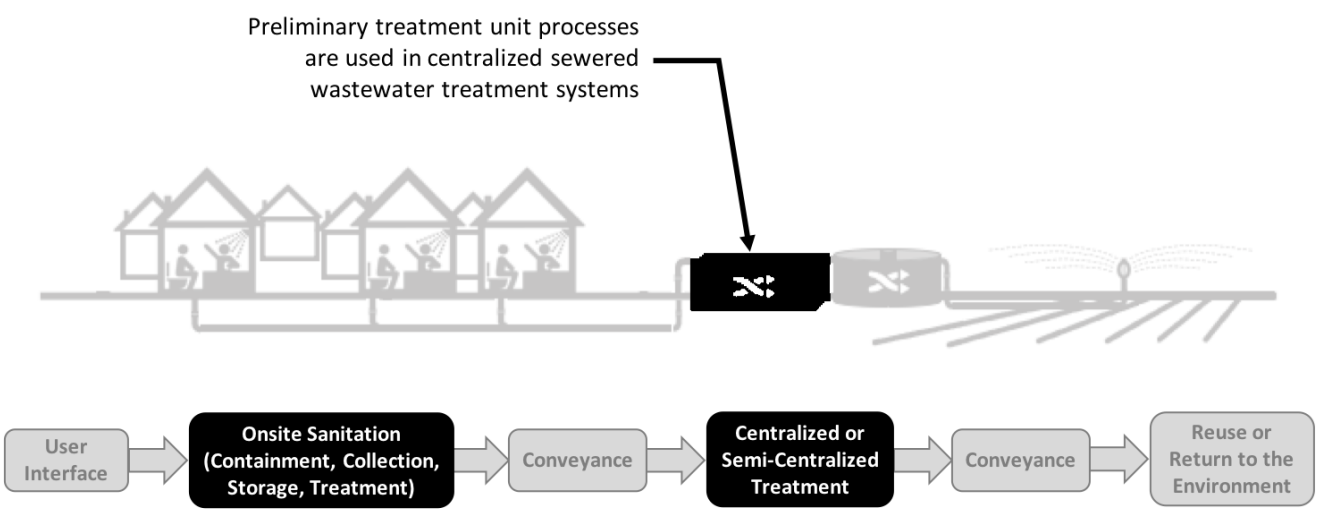

Figure 1. Locations where preliminary treatment is used within the sanitation service chain. 

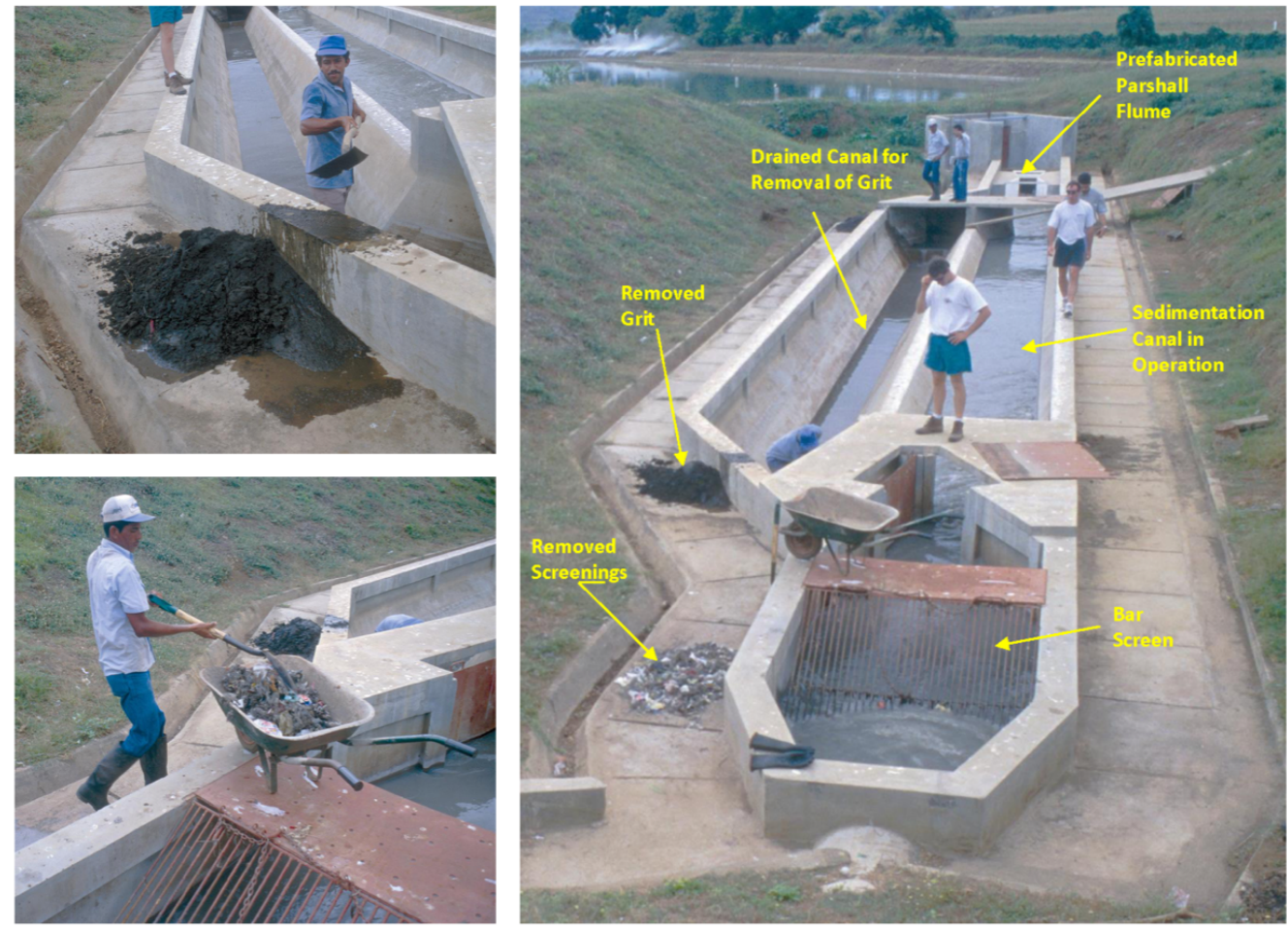

Figure 2. A manual preliminary treatment process with bar rack and horizontal grit chamber for a small wastewater stabilization pond system in León, Nicaragua. Screenings are removed by hand and should be buried or incinerated onsite. Grit, also removed manually, should be buried or stored onsite depending on quantities produced. (photos reproduced with permission of Stewart Oakley)

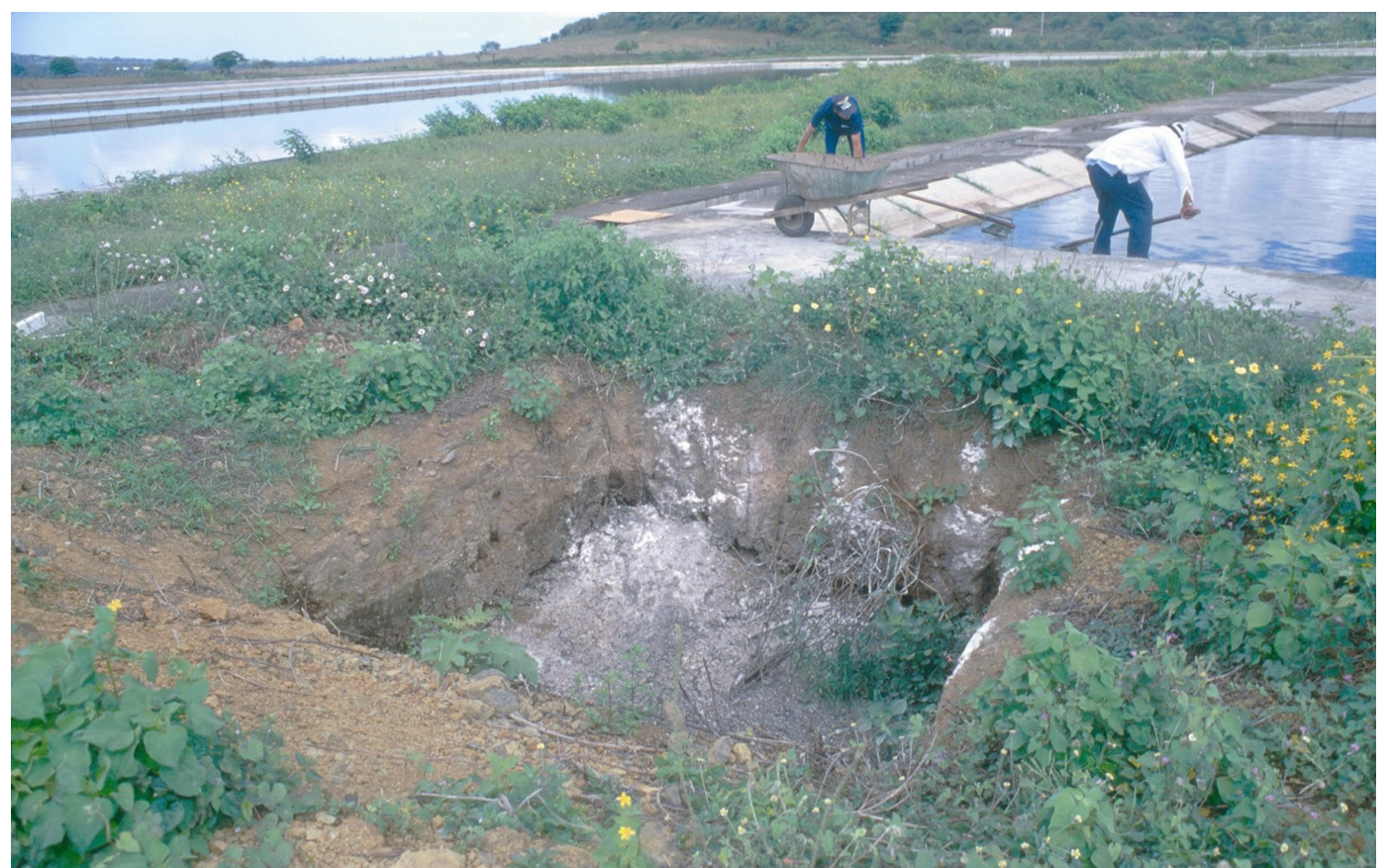

Figure 3. An excavation for disposal of screenings at a wastewater stabilization pond system in Masaya, Nicaragua. Lime is placed on top of the materials for odor control and partial disinfection. (photo reproduced with permission of Stewart Oakley) 


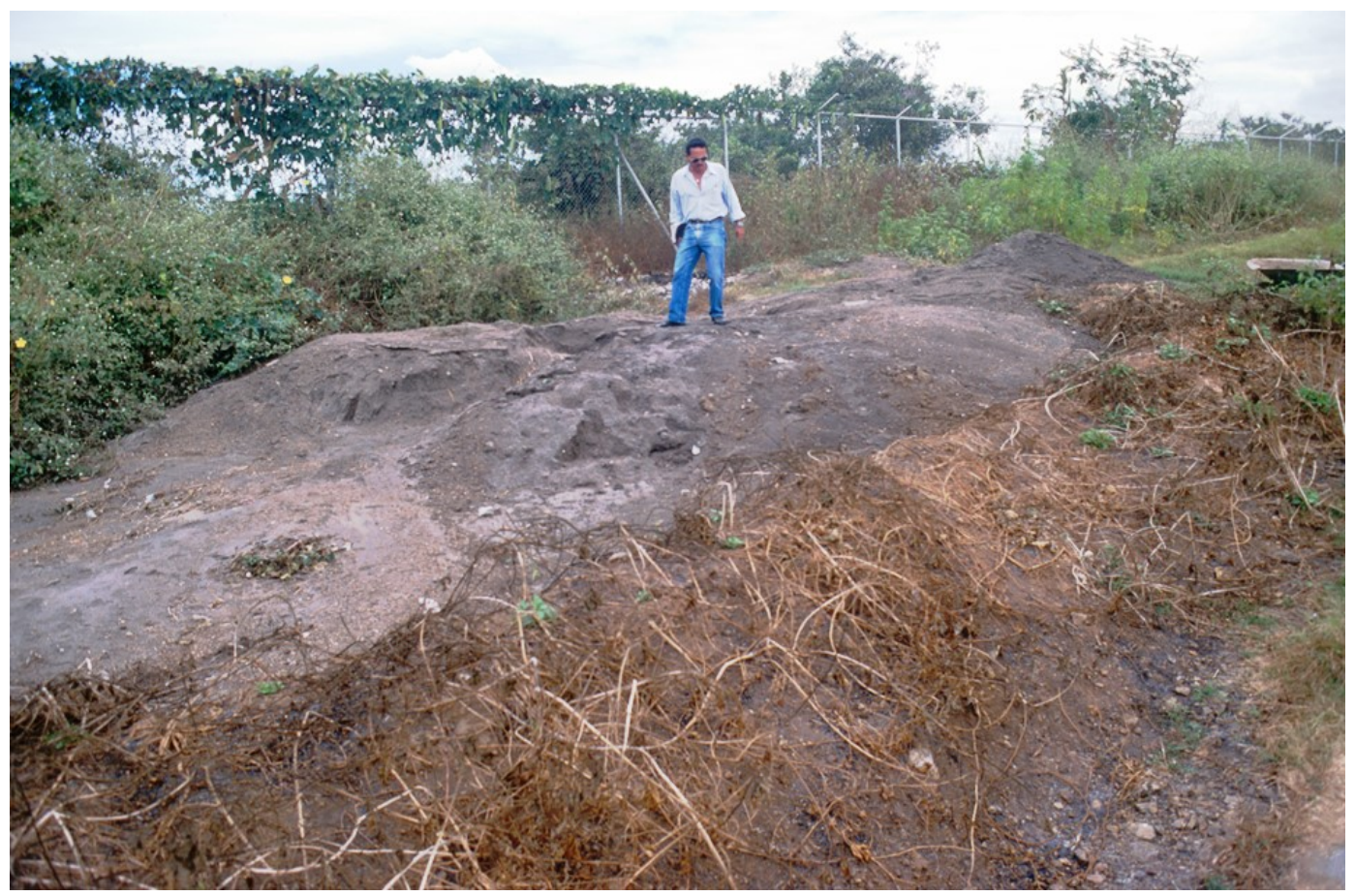

Figure 4. Grit storage at a wastewater stabilization pond system in León, Nicaragua. Note the facility is fenced to prevent unauthorized entry. (photo reproduced with permission of Stewart Oakley)
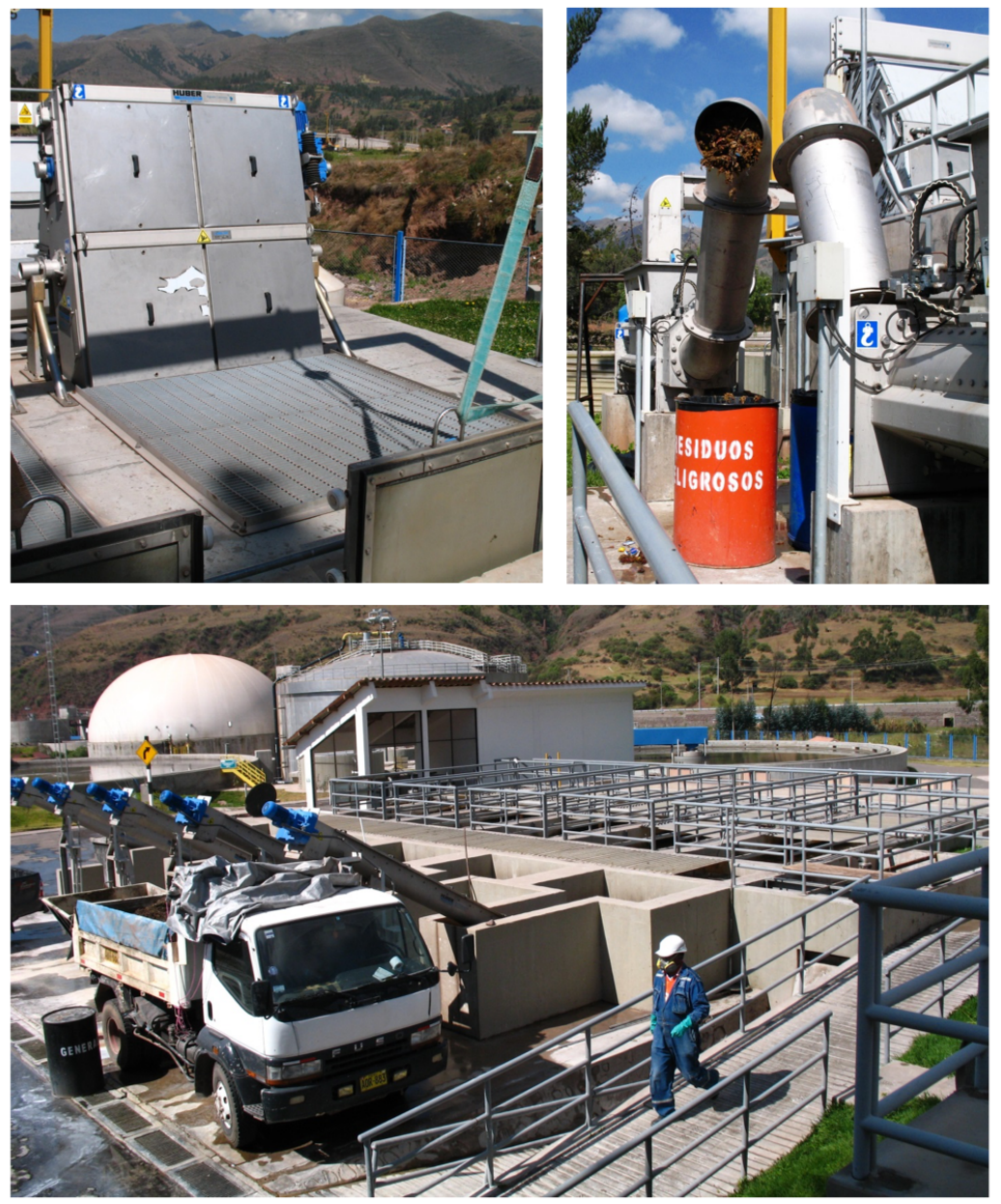

Figure 5. A mechanized preliminary treatment system at the Cuzco, Peru wastewater treatment facility. The photos show the covered bar rack (top left) and mechanical disposal of screenings (top right) and the bottom photo the aerated grit chamber with mechanical disposal directly into trucks. As is often the case in developing countries, the screenings and grit are disposed in a poorly operated landfill and there is a high risk of pathogen release to the environment. (photo reproduced with permission of Stewart Oakley) 
Production of screenings can range between 6-50 Liters $/ 1,000 \mathrm{~m}^{3}$ of wastewater treated depending on the size of the openings. Grit production is highly dependent on local conditions and ranges from 4-37 Liters $/ 1,000 \mathrm{~m}^{3}$ for sanitary sewers without stormwater inputs (Metcalf and Eddy/AECOM, 2014). Detailed information on the design and operation of preliminary treatment processes can be found in Mara (2003), Metcalf and Eddy/AECOM (2014), and USEPA (2003).

\subsection{Inputs and Outputs}

As Feachem et al. (1983) noted, preliminary treatment is not expected to remove pathogens in the liquid stream, and a few studies have reported quantitative data to this effect (Marin et al., 2015). Screenings and grit will be expected to contain high concentrations of pathogens, and this has occasionally been reported in the literature (Marin et al., 2015; Szostkova et al., 2012). Several investigators have also noted elevated concentrations of airborne microorganism indicators (bioaerosols) and detection of antibiotic resistant genes in enclosed mechanized preliminary treatment facilities as shown in Table 1 (Heinonen-Tankski et al., 2009; Li et al., 2016). Figure 6 illustrates the inputs and outputs for preliminary treatment processes.

Table 1. Airborne microorganisms and antibiotic resistant genes detected in preliminary treatment.

\begin{tabular}{|c|c|c|c|c|}
\hline \multirow[b]{2}{*}{ Description/Reference } & \multicolumn{4}{|c|}{ Concentration Range/Detection } \\
\hline & Indicator & $\begin{array}{l}\text { Screening } \\
\text { Room }\end{array}$ & $\begin{array}{c}\text { Aerated } \\
\text { Grit } \\
\text { Chamber } \\
\end{array}$ & Reference \\
\hline \multirow{3}{*}{$\begin{array}{l}\text { China (Beijing) Large WWTP } \\
\left(400,000 \mathrm{~m}^{3} / \text { day) }\right.\end{array}$} & $\begin{array}{c}\text { Culturable } \\
\text { Bacterial } \\
\text { Aerosols, } \\
\text { CFU } / \mathrm{m}^{3}\end{array}$ & $1.2 \mathrm{E}+03$ & $460^{2}$ & \\
\hline & $\begin{array}{c}\text { Fungal } \\
\text { Aerosols, } \\
\text { CFU } / \mathrm{m}^{3}\end{array}$ & 487 & $523^{2}$ & Li et al., 2016 \\
\hline & $\begin{array}{c}\text { Antibiotic } \\
\text { Resistant } \\
\text { Genes }\end{array}$ & $\begin{array}{l}\text { Detection of } \\
\text { Sulfonamide } \\
\text { and Integrase }\end{array}$ & & \multirow{5}{*}{$\begin{array}{l}\text { Heinonen-Tankski et } \\
\text { al., } 2009\end{array}$} \\
\hline \multirow{4}{*}{$\begin{array}{l}\text { Finland } \\
\text { Seven WWTPs }\end{array}$} & $\begin{array}{c}\text { Fecal } \\
\text { coliforms, } \\
\text { CFU } / \mathrm{m}^{3}\end{array}$ & $<3.5$ to 472 & $<3.5$ to 279 & \\
\hline & $\begin{array}{c}\text { Enterococci, } \\
\text { CFU } / \mathrm{m}^{3} \\
\text { Somatic }\end{array}$ & $<3.5$ to 165 & $<3.5$ to 395 & \\
\hline & $\begin{array}{l}\text { coliphages, } \\
\mathrm{PFU} / \mathrm{m}^{3}\end{array}$ & $\mathrm{ND}^{1}$ to 380 & $\mathrm{ND}^{1}$ to 240 & \\
\hline & $\begin{array}{c}\text { F-specific } \\
\text { coliphages, } \\
\text { PFU } / \mathrm{m}^{3}\end{array}$ & $\mathrm{ND}^{1}$ to 30 & $\mathrm{ND}^{1}$ to 70 & \\
\hline
\end{tabular}

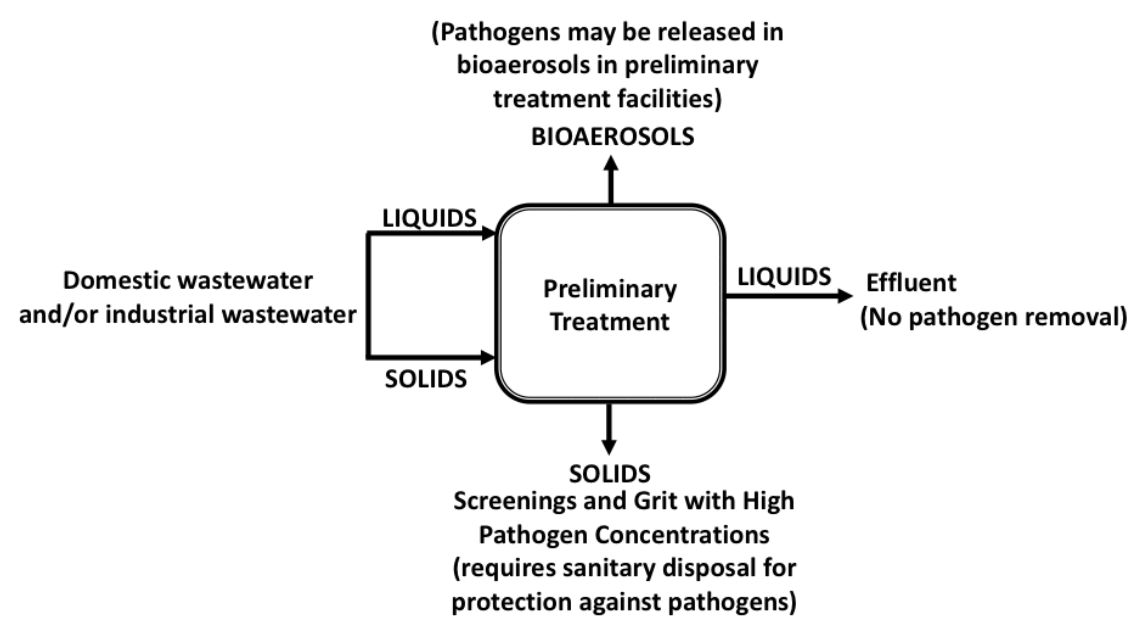

Figure 6. Typical inputs and outputs for preliminary treatment 


\subsection{Factors Affecting Pathogens}

As discussed above, preliminary treatment will have little effect on pathogen removal in the liquid wastestream. Screenings and grit will contain high concentrations of pathogens and must be safely treated and/or disposed to protect public health. Mechanized facilities in indoor enclosures could potentially have elevated concentrations of airborne pathogens if proper air filtration/ventilation is not used; outdoor mechanized facilities (shown previously in Figure 5) could also have high airborne concentrations if they are not covered.

\subsection{Design, Operation, and Maintenance Guidelines for Pathogen Risks}

There is little that can be done to enhance the removal of pathogens in the liquid wastestream in preliminary treatment. The design engineer should ensure, however, that facilities and training exist for the safe treatment and/or disposal of screenings and grit. This is especially important in developing countries where open dumps are common and it cannot be assumed materials will be buried offsite in a sanitary landfill. In this case, treatment plant designs should include onsite disposal of screenings and grit (as was shown in Figures 2 through 5). Operation and maintenance manuals should include detailed discussion of the safe handling and disposal of screenings and grit, and operators should receive proper training.

Design of large-scale mechanized facilities should consider the possibility for airborne pathogens. Therefore, they should consider: (1) enclosed preliminary treatment units that are designed with proper ventilation and air filtration and (2) outdoor preliminary treatment units that are covered.

\subsection{Primary Sedimentation}

\subsection{Brief Technology Description}

The objective of primary sedimentation (also known as primary treatment) is the removal of settleable organic solids and floating organic material (called scum) in order to reduce the suspended solids load for downstream treatment processes (Metcalf and Eddy/AECOM, 2014)). Scum is usually disposed separately or in combination with sludge/biosolids in wastewater treatment plants. No literature data were found on pathogen concentrations in scum, but it can be assumed to have significant concentrations and should be handled accordingly. Primary sedimentation is a form of centralized or semicentralized wastewater treatment and is an integral part of conventional wastewater treatment (primary and secondary treatment) as developed historically and practiced today (Figures 7 and 8). Primary sedimentation tanks can be rectangular or circular, and typically operate with a hydraulic detention time of 1.5-3 hours based on the average daily flowrate (Figures 9 and 10). The settled primary sludge solids, which are highly putrescible, must be continuously removed from the bottom of the sedimentation tank and stabilized, usually by anaerobic digestion and less frequently by aerobic digestion (see Chapter on Sludge Management). Primary sludge typically contains 2 to $5 \%$ total solids with 60 to $80 \%$ organic content.

Typical performance data for the removal of total suspended solids (TSS) and biochemical oxygen demand (BOD5) in primary sedimentation tanks are shown in Figure 11. Primary treatment can remove up to $70 \%$ TSS and 45\% BOD5 (Metcalf and Eddy/AECOM, 2014)). Primary effluent requires downstream secondary treatment for further removal of organic matter, usually aerobic technologies (e.g., chapter on Activated Sludge, chapter on Media Filters such as a trickling filter) or natural system technologies (e.g., chapter on Constructed Wetlands). 


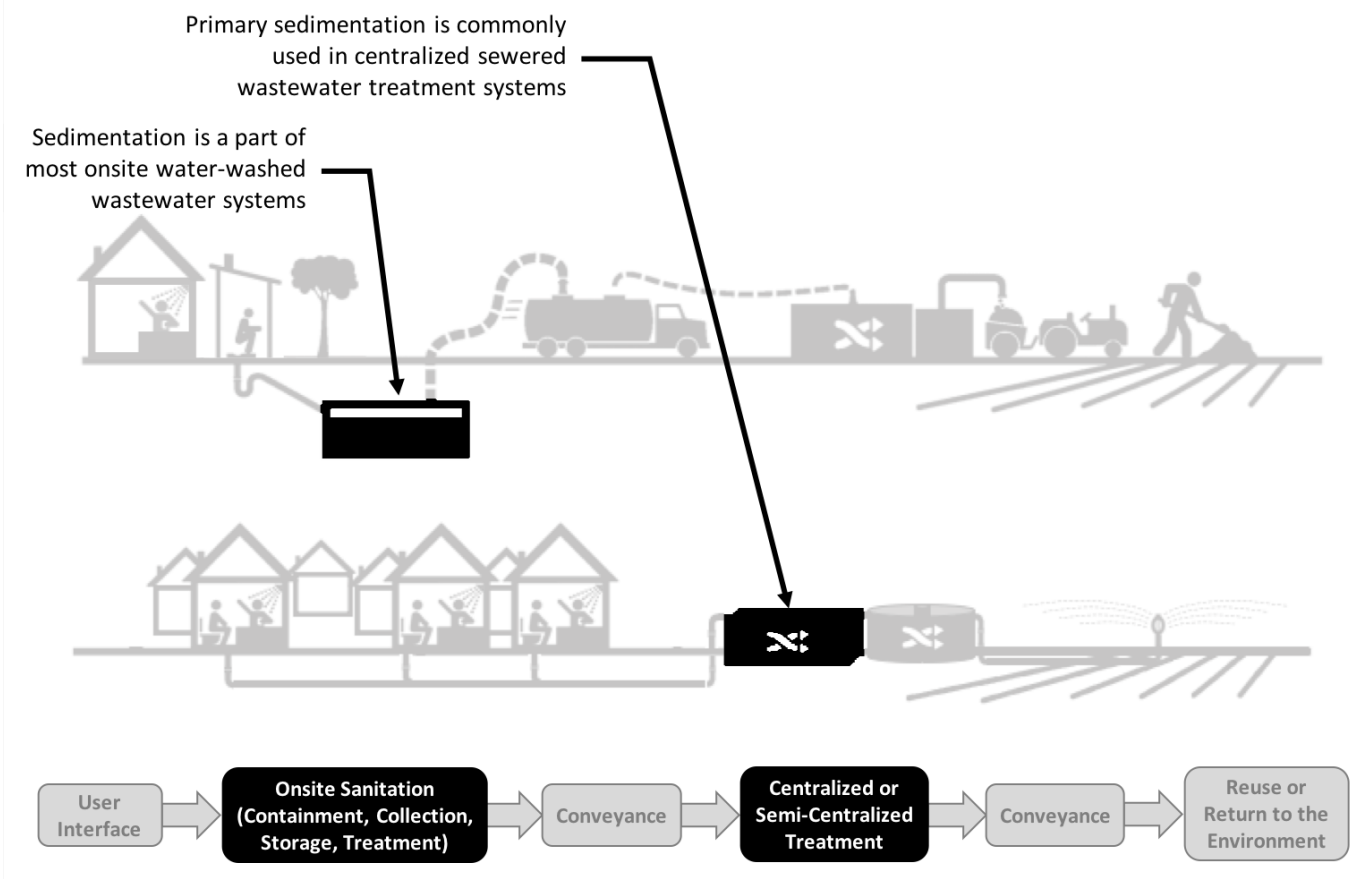

Figure 7. Locations where primary sedimentation is used within the sanitation service chain

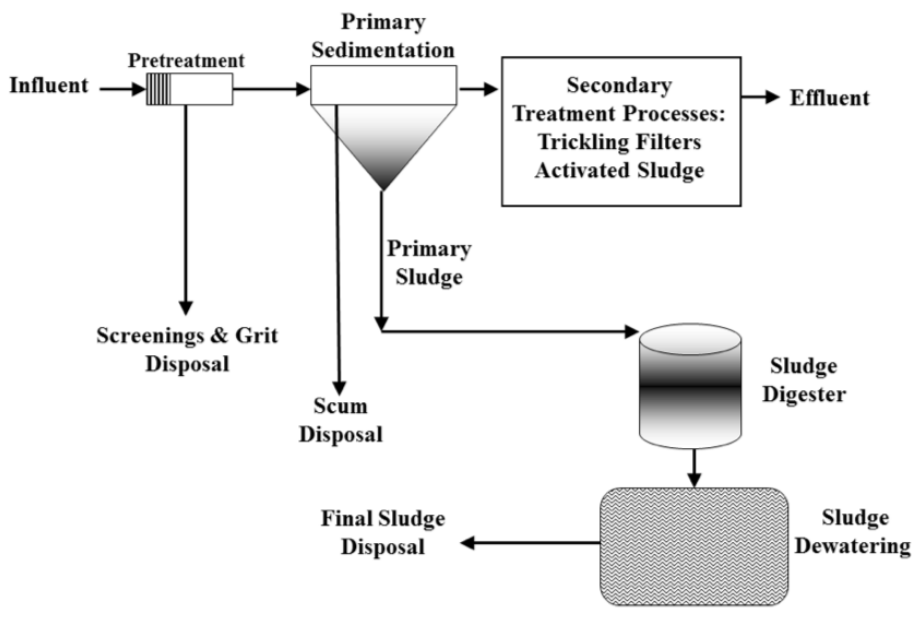

Figure 8. Primary sedimentation within the framework of conventional primary and secondary treatment of wastewater and sludge management 

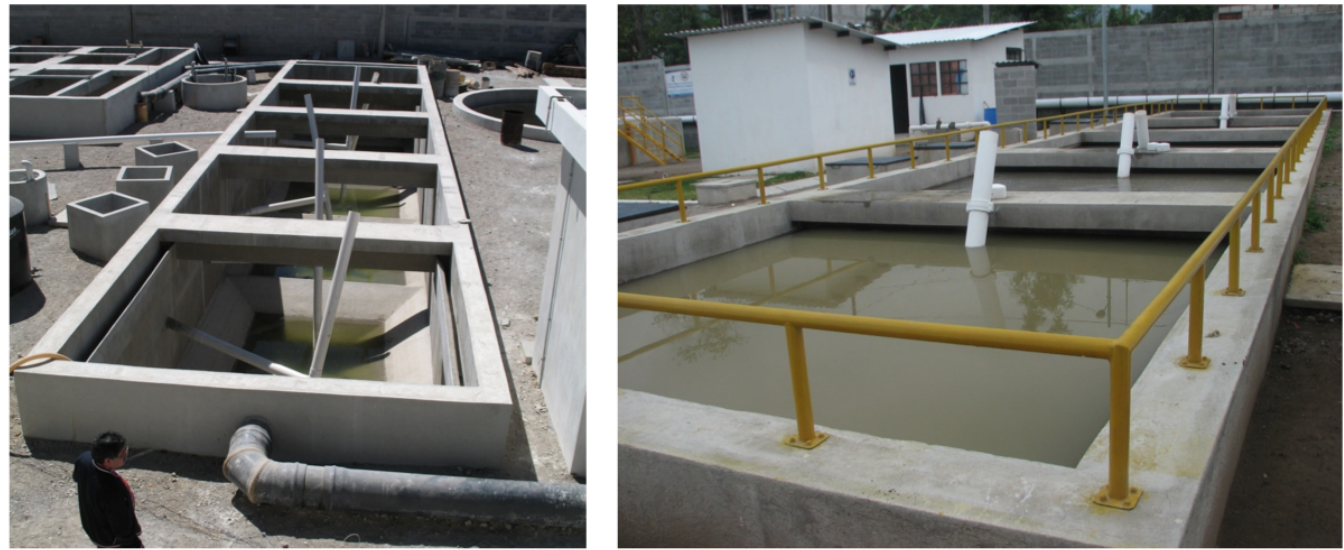

Figure 9. A hopper-type rectangular sedimentation tank where settled solids are removed by hydrostatic pressure (left photo is the tank under construction; right photo is the tank in operation) (Panajachel, Guatemala) (photo reproduced with permission of Stewart Oakley)

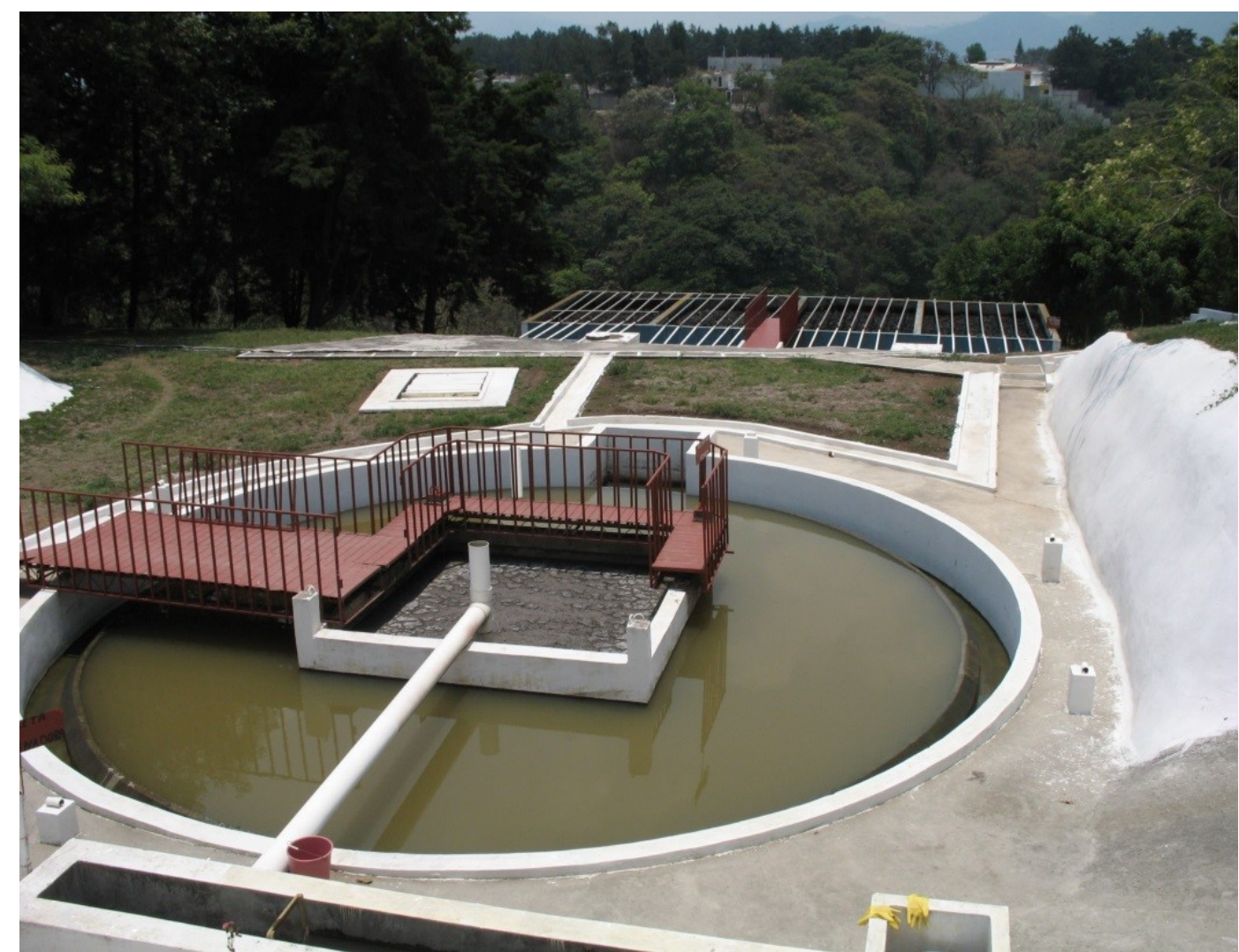

Figure 10. A circular primary sedimentation tank discharging to a trickling filter. (University of San Carlos, Guatemala) (photo reproduced with permission of Stewart Oakley) 


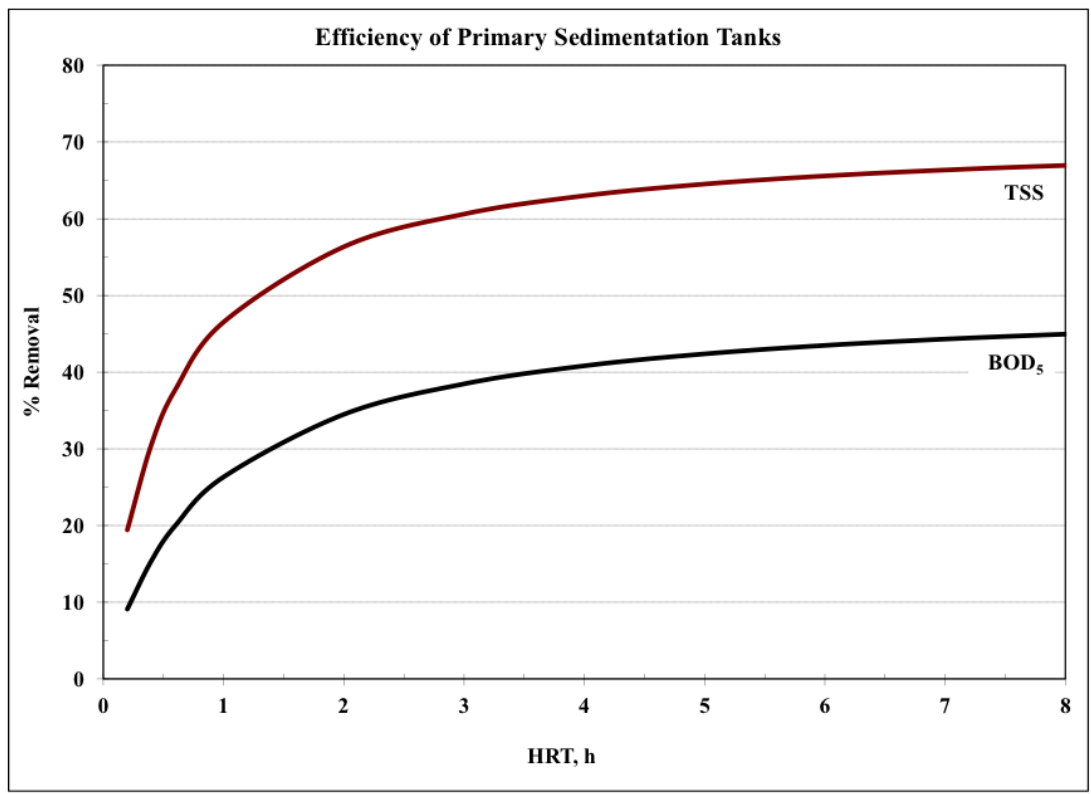

Figure 11. Efficiency of removal of total suspended solids (TSS) and five-day biochemical oxygen demand (BOD ( $_{5}$ in primary sedimentation tanks as a function of hydraulic retention time (HRT in hours) (developed from equations available in Metcalf and Eddy/AECOM, 2014))

The removal of pathogens during primary treatment is not high, therefore downstream treatment will require pathogen removal technologies in addition to organic matter removal to meet discharge or reuse requirements. Primary sedimentation (including Imhoff tanks) produces from $110-170 \mathrm{~kg}$ dry solids/1,000 $\mathrm{m}^{3}$ wastewater treated (Andreoli et al., 2007; Metcalf and Eddy/AECOM, 2014), and this sludge must be stabilized, dewatered, and treated for pathogens before reuse as discussed in the chapter on Sludge Management.
Imhoff tanks are primary sedimentation tanks that include additional volume for settled sludge storage and anaerobic digestion. They are designed for small flows and are still commonly used in developing countries. As shown in Figures 12 and 13, an Imhoff tank consists of: (1) a V-shaped settling compartment, (2) a large compartment underneath the settling compartment for settled sludge storage and digestion, and (3) separate compartments for biogas venting and scum removal. Imhoff tanks are used in small communities because of low investment costs and simple operation and maintenance (Tilly et al., 2014). As with primary sedimentation tanks, the effluents from Imhoff tanks require further treatment before discharge or reuse. The sludge withdrawn from Imhoff tanks, which should be well digested before withdrawal, is typically dewatered in sludge drying beds.

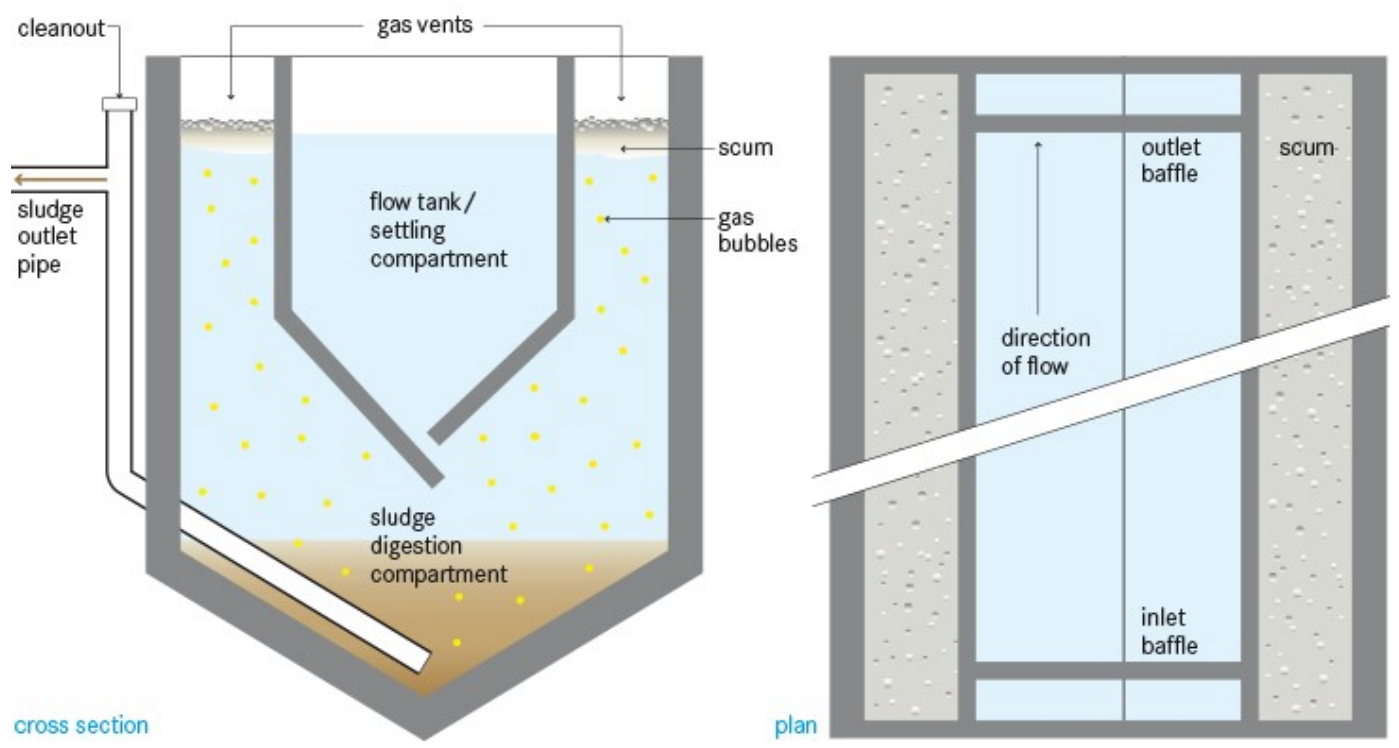

Figure 12. A section and plan view of an Imhoff tank. The sludge digestion compartment can be as deep as $6 \mathrm{~m}$ to store and digest primary sludge. (Reprinted with permission of Eawag: Swiss Federal Institute of Aquatic Science and Technology, Department Water and Sanitation in Developing Countries (Sandec). Figure from Tilly et al. (2014) Compendium of Sanitation Systems and Technologies. 2nd Revised Edition. Swiss Federal Institute of Aquatic Science and Technology (Eawag). Dübendorf, Switzerland) 


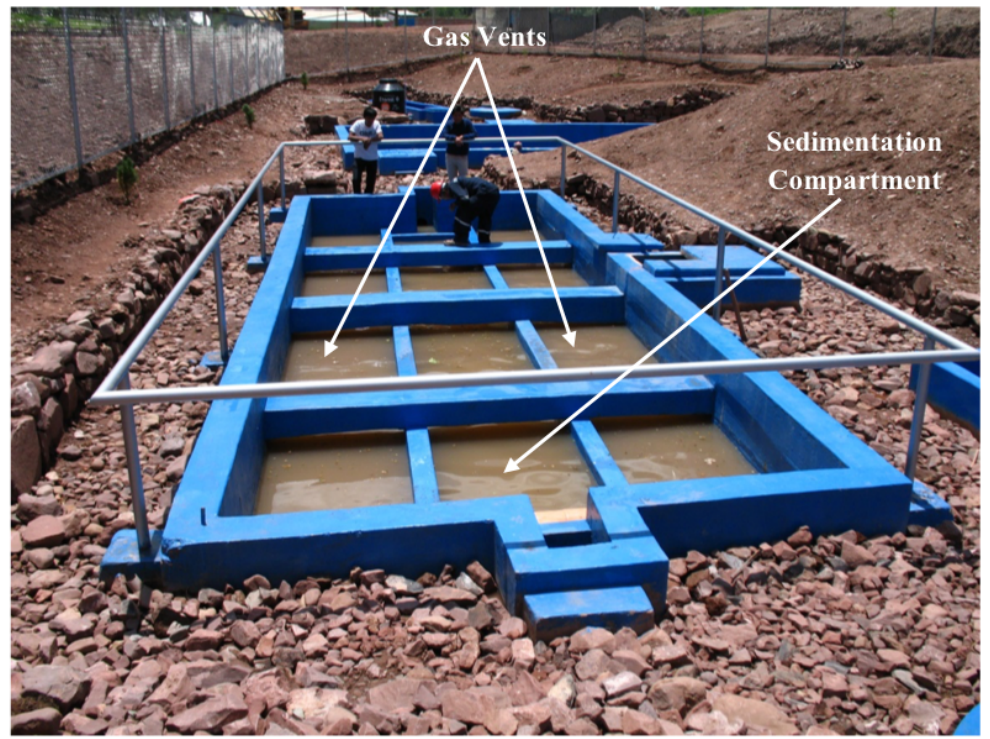

Figure 13. An Imhoff tank at completion of construction. This tank has a depth of $6 \mathrm{~m}$ and is below the groundwater table; as a result a curtain drain was installed to divert groundwater flow. (Saylla, Peru) (photo reproduced with permission of Stewart Oakley)

Chemically enhanced primary treatment (CEPT) and advanced primary treatment (APT) (also called high-rate clarification) can be used to improve the performance of primary sedimentation; CEPT uses a coagulationflocculation process with conventional primary sedimentation while APT uses coagulation-flocculation with a high-rate lamellar settler for much shorter hydraulic retention times (Metcalf and Eddy/AECOM, 2014). Both processes can increase TSS removal to $80-90 \%$ (Metcalf and Eddy/AECOM, 2014) and have been proposed to specifically remove helminth eggs from untreated wastewater (Jimenez et al., 2010).

Detailed information on the design and operation of primary sedimentation processes, including CEPT and APT, can be found in and Metcalf and Eddy/AECOM (2014). Tilly et al. (2014) present information on the design and operation of Imhoff tanks. Historical information on pathogen fate in primary treatment and wastewater treatment systems is available in Feachem et al. (1981, 1983).

\subsection{Inputs and Outputs}

Primary sedimentation is used to treat the following liquid waste streams: domestic wastewaters, a variety of industrial wastewaters, combined domestic/industrial wastewaters, stormwater, and livestock facility wastewaters (Figure 14). Primary sedimentation tanks receive untreated wastewaters that typically have received pretreatment (screening and grit removal). Typical concentrations of pathogens in influent wastewaters are provided in the Introduction chapter. The outputs from primary sedimentation processes include primary effluent and primary sludge, both of which require further treatment for stabilization and pathogen removal: primary effluent is typically treated by aerobic secondary processes (e.g., trickling filters, activated sludge, etc.) and also anaerobic processes (e.g., anaerobic filter); primary sludge, which is continuously removed from sedimentation tanks in centralized systems, is most commonly stabilized by anaerobic digestion and then dewatered.

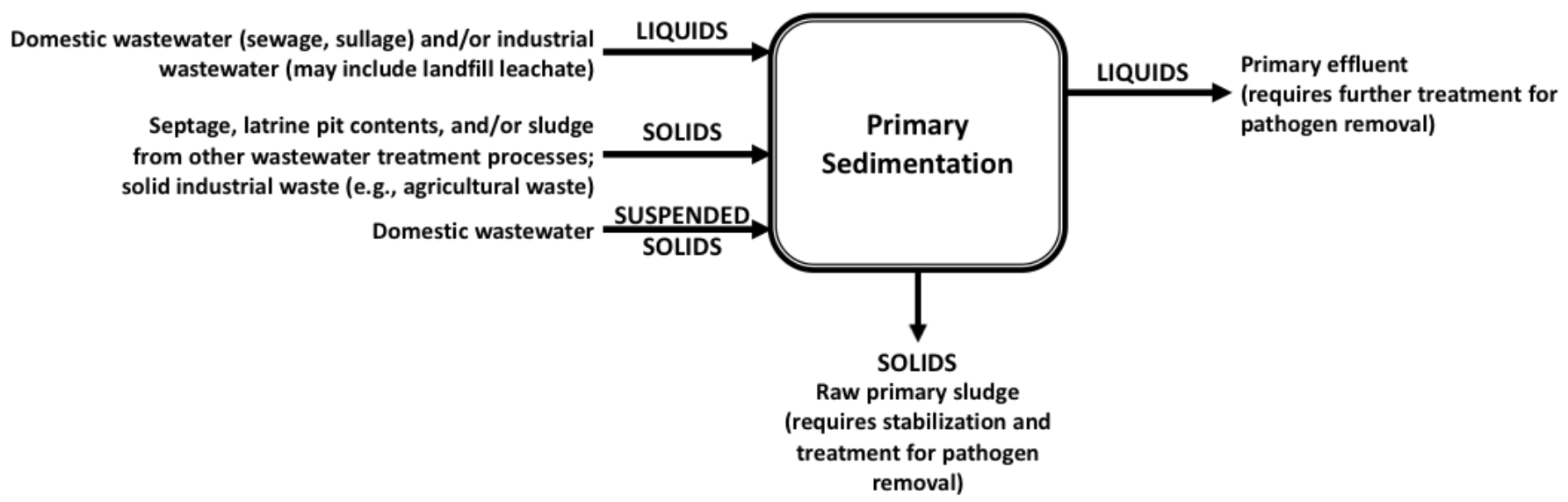

Figure 14. Typical inputs and outputs for primary sedimentation processes 


\subsection{Factors Affecting Pathogens in Primary Sedimentation Processes}

Conventional primary sedimentation processes are designed specifically for suspended solids removal and any removal of viral, bacterial, protozoan or helminth pathogens is incidental to the design objectives. The reduction of viral, bacterial, and protozoan pathogens has been reported to range from 0 to $1 \log _{10}$ units, and from 0 to $<1 \log _{10}$ for helminths, for conventional primary sedimentation (WHO, 2006). CEPT and APT processes, however, have been proposed for helminth egg removal and removals from 1 to $3 \log _{10}$ have been reported (WHO, 2006). Furthermore, removal rates from 1 to $2 \log _{10}$ for viruses, bacteria, and protozoa have also been reported in the literature for CEPT/APT (WHO, 2006).

A summary of the most important factors for removal of the different pathogen types is presented in Table 2. The principal removal mechanism for pathogens is sedimentation by retention in settling floc particles, whether in conventional or CEPT/APT processes (Figure 15). The retention in the settling floc can be due to adsorption to surfaces or entrapment within the matrix of the settling floc particles (Jimenez et al., 2010).

Table 2. Summary of factors and mechanisms for indicator pathogen removal in primary sedimentation.

\section{Evidence of Indicator or Pathogen Vulnerability}

\section{1..Conventional Primary Treatment}

Retention in settling floc

Mechanisms: Removal of pathogens is very low and only occurs by sedimentation through pathogen retention in settling flocs. A small percentage of pathogens are retained in flocs by coalescence/adsorption or entrapment within floc matrix, but the majority exit in the primary effluent. Important factors limiting removal include

- Design overflow rates and corresponding settling velocities for primary sedimentation tanks are much greater than that required for pathogen removal by sedimentation, including those with the highest settling velocities (helminth ova).

- The fraction of pathogens associated with settleable solids has a direct effect on removal.

\begin{tabular}{lcc}
$\begin{array}{l}\text { Area/ } \\
\text { description of } \\
\text { study }\end{array}$ & $\begin{array}{c}\text { Indicator or } \\
\text { Pathogen }\end{array}$ & Log10 removal Reference \\
\hline
\end{tabular}

Viruses

Argentina,

Colombia and

France

primary

clarifiers for

treatment

somatic coliphages, F-specific RNA

bacteriophages and bacteriophages infecting Bacteroides fragilis

plants

Canada

WWTP

Somatic coliphage

0.17

Coliphages

0

WWTP

Spain

(Barcelona)

WWTP

Rotavirus and enterovirus

1.4 to 1.8

0.7

Norovirus

(Gothenburg)

WWTP

Bacteria

Argentina,

Colombia and

France in

primary

clarifiers for

treatment

plants.
Fecal coliform, fecal enterococci, and sulfite reducing clostridia spore
Lucena et al., 2004

Chauret et al. 1999

Tanji et al., 2002

Bosch et al., 1986

Nordgren et al., 2009 


\begin{tabular}{lcc}
$\begin{array}{l}\text { Area/ } \\
\text { description of } \\
\text { study }\end{array}$ & Indicator or & Log10 removal \\
\hline
\end{tabular}

\begin{tabular}{|c|c|c|c|}
\hline \multicolumn{4}{|l|}{ Bacteria } \\
\hline $\begin{array}{l}\text { Belgium and } \\
\text { France } \\
\text { geometric mean } \\
\text { log10 removal } \\
\text { for } 12 \text { WWTPs }\end{array}$ & Fecal coliforms & 0.15 & $\begin{array}{l}\text { George et al. } \\
\quad(2002)\end{array}$ \\
\hline $\begin{array}{l}\text { Canada } \\
\text { using real-time } \\
\text { quantitative }\end{array}$ & Clostridium perfringens & 1.32 to 2.39 & \\
\hline $\begin{array}{l}\text { PCR for } \\
\text { detection of } \\
\text { bacterial }\end{array}$ & Escherichia coli & 1.72 to 2.13 & \\
\hline $\begin{array}{l}\text { pathogens and } \\
\text { indicators, } \\
\text { calculated the }\end{array}$ & Enterococcus faecalis & -0.14 to 0.88 & $\begin{array}{c}\text { Shannon et al. } \\
2007\end{array}$ \\
\hline $\begin{array}{l}\text { following } \\
\text { removal ranges }\end{array}$ & Klebsiella pneumoniae & 0.76 to 2.63 & \\
\hline $\begin{array}{l}\text { for primary } \\
\text { effluent WWTP }\end{array}$ & Pseudomonas aeruginosa & 1.85 to 2.16 & \\
\hline $\begin{array}{l}\text { Spain } \\
\text { (Barcelona) } \\
\text { WWTP }\end{array}$ & $\begin{array}{c}\text { Fecal coliform } \\
\text { Fecal streptococci }\end{array}$ & $\begin{array}{l}0.4 \\
0.1\end{array}$ & $\begin{array}{l}\text { Bosch et al., } \\
1986\end{array}$ \\
\hline \multicolumn{4}{|l|}{ Protozoa } \\
\hline $\begin{array}{l}\text { Canada } \\
\text { WWTP }\end{array}$ & Giardia cysts & 0.11 & $\begin{array}{c}\text { Chauret et al., } \\
1999\end{array}$ \\
\hline \multicolumn{4}{|l|}{ Helminths } \\
\hline & Eggs & 0 to 1 & $\begin{array}{l}\text { WHO, 2006; } \\
\text { Jimenez et al., } \\
2010\end{array}$ \\
\hline
\end{tabular}

2. Chemically Enhanced/Advanced Primary Treatment (CEPT/APT)

Retention in settling floc

Mechanisms: Removal of helminth eggs is enhanced by coagulation-flocculation with ferric or aluminum salts, lime, and polymers. Removal of viruses, bacteria and protozoa by CEPT/APT processes may be slightly higher $(\approx 0.1-0.8$ $\log 10$ ) than conventional primary sedimentation. CEPT/APT effluent, however, requires filtration to meet WHO reuse guidelines for helminth eggs (<1 egg/L) (Jimenez-Cisneros et al., 2001).

- Sedimentation basin hydraulics can have a significant effect on suspended solids and pathogen removal (shown in Figure 16).

Viruses

\begin{tabular}{|c|c|c|c|}
\hline \multirow{3}{*}{$\begin{array}{l}\text { Canada (Guelph) } \\
\text { WWTP with FeCl3 } \\
\text { as a coagulant }\end{array}$} & Somatic coliphage & \multirow{2}{*}{0.3 to 1.4} & \multirow{3}{*}{$\begin{array}{c}\text { Zhang and } \\
\text { Farahbakhsh, } \\
2007\end{array}$} \\
\hline & & & \\
\hline & F-specific coliphage & 0.4 to 1.9 & \\
\hline $\begin{array}{l}\text { Canada } \\
\text { (Montreal) } \\
\text { Advanced } \\
\text { primary } \\
\text { treatment plant }\end{array}$ & Enteric viruses & 0 & $\begin{array}{c}\text { Payment et al., } \\
2001\end{array}$ \\
\hline $\begin{array}{l}\text { Spain } \\
\text { (Barcelona) } \\
\text { WWTP }\end{array}$ & Rotavirus & -0.1 & Bosch et al., \\
\hline $\begin{array}{l}\text { coagulation } \\
\text { with lime }\end{array}$ & Enterovirus & -0.8 & 1986 \\
\hline
\end{tabular}




\section{Area/ \\ description of study}

Viruses

Spain

WWTP

With $\mathrm{FeCl}_{3}$

coagulant

With lime

Bacteria

\section{Canada}

(Guelph)

WWTP

Fecal coliforms

F-RNA specific bacteriophages, bacteriophages of Bacteroides fragilis

F-RNA specific bacteriophages
0.3 to 0.7

Lucena et al., 2004

Mexico (Mexico

City)

APT processes

treating

wastewater at

laboratory or

pilot scale

Canada

(Montreal)

Advanced

primary

treatment plant

Spain

WWTP

With $\mathrm{FeCl}_{3}$

coagulant

With lime

coagulant

Protozoa
Fecal coliforms

0.67 to 1.3

Salmonella sp.

Clostridium perfringens

Escherichia coli

Fecal coliforms

Fecal streptococci

Fecal coliforms, fecal enterococci

Fecal coliforms

Fecal enterococci
1.0 to 1.6

Zhang and

0.82

Farahbakshs (2007)

Jimenez et al., 2001 ; Jimenez and Chavez, 2002 ; Chavez et al., 2004

0.06

0.12

Payment et al., 2001

0.15

0.3 to 0.7

2.0

Lucena et al., 2004

\section{Mexico (Mexico}

City)

APT processes

for pilot plants

Canada

(Montreal)

Advanced

primary

treatment plant

Helminths

Laboratory and

pilot scale

Jar test

Pilot plant

Pilot plant

Jar test
Giardia lamblia, Entamoeba coli, and

E. histolytica cyst

0.49

Jimenez et al., 2001

Cryptosporidium parvum

0.14

Giardia lambila

0.62
Payment et al., 2001
Jimenez-

Cisneros and

Chavez-Mejia 1997; Jimenez

et al., 2001;

Jimenez and

Chavez 2002;

Chavez et al., 2004 


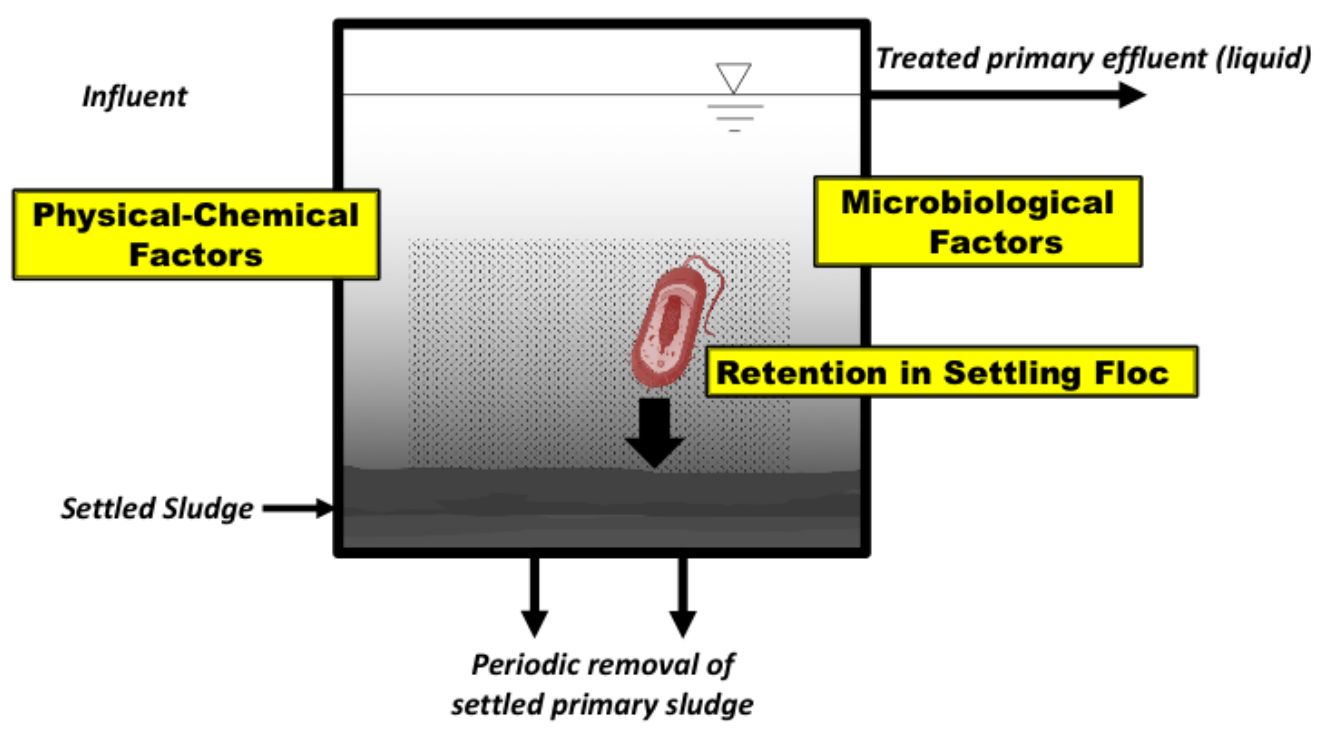

Figure 15. Major factors affecting pathogens in primary sedimentation

\subsection{Sedimentation by Retention in Settling Floc Particles}

There are little data in the literature on the mechanism of pathogen retention in settling flocs in primary sedimentation processes. As a result, it is assumed that retention in settling floc particles is similar to the processes forming the flocs, which includes (Metcalf and Eddy/AECOM, 2014): (1) coalescence of fine particles, which gradually form settleable flocs, and (2) rate of coalescence, which is a function of the concentration of particles and their natural ability to coalesce upon collision. CEPT/APT processes enhance floc formation of fine particles and, as a result, more pathogens, especially large ones such as helminth eggs, will coalesce into the settleable floc particles.

The sedimentation of discrete helminth eggs (i.e., not attached to wastewater solids) does not occur in conventional primary sedimentation tanks. Design guidelines specify overflow rates of $30-50 \mathrm{~m} 3 / \mathrm{m} 2$-d (meters cubed per meters squared per day) at average flow and 80-120 m3/m2-d for peak hourly flows (Metcalf and Eddy/AECOM, 2014)). These overflow rates are equivalent to settling velocities of 1.2-2.0 $\mathrm{m} / \mathrm{h}$ (meters per hour) at average flow and 3.3-5.0 $\mathrm{m} / \mathrm{h}$ at peak flow. Experimentally measured settling velocities for helminth eggs in treated water have been reported to average $0.22 \mathrm{~m} / \mathrm{h}$ for Ascaris and $0.54 \mathrm{~m} / \mathrm{h}$ for Trichuris (Sengupta et al., 2011). These settling velocities are equivalent to overflow rates of 5.3 and $13 \mathrm{~m} 3 / \mathrm{m} 2-\mathrm{d}$, respectively. Thus sedimentation basins would require a surface area approximately 6 times larger than conventional designs for the same flowrate to remove discrete Ascaris eggs.
Settling velocities for individual protozoa, bacteria, and viruses are even much lower than those of helminth eggs (Cizek et al., 2008; David and Lindquist, 1982; Kulkarni et al., 2004; Medema et al., 1998). Thus, it is not expected that these pathogens would be removed by settling during conventional primary treatment when not attached to particles.

\subsection{Additional Physical Factors}

The physical factors that affect the performance of sedimentation tanks can also be expected to influence pathogen removal by sedimentation. These factors include temperature and wind effects as shown in Figure 16. Temperature differences of $1{ }^{\circ} \mathrm{C}$ between influent wastewater and the wastewater in the sedimentation tank can cause density currents to form, causing hydraulic short circuiting (Figure 16b); in addition, sedimentation efficiency is a function of water temperature, and colder temperatures increase water viscosity and retard particle settling (Metcalf and Eddy/AECOM, 2014). Wind blowing across the surface of sedimentation tanks can cause circulation cells to form, reducing the volumetric capacity of the tank (Figure $16 d)$.

Peak wastewater flows can also significantly reduce the performance of sedimentation tanks, which are designed for the average daily flow with hydraulic retention times from 1.5 to 2.5 hours. Peak flows can range from 2 to 3 times the average flow, thus decreasing the hydraulic residence time (HRT) to 0.67 to 1 hour if the tank were designed for a 2 hour HRT at average daily flow. It can thus be assumed there would be very little pathogen removal under these conditions. 
Design engineers can minimize these hydraulic impacts and ensure adequate performance by designing for: (1) peak flows and average daily flows with a safety factor to cover adequate ranges of HRT and overflow rates; (2) the temperature of water during the coldest months; and (3) scour velocities below the peak flow horizontal velocity (Metcalf and Eddy/AECOM, 2014).

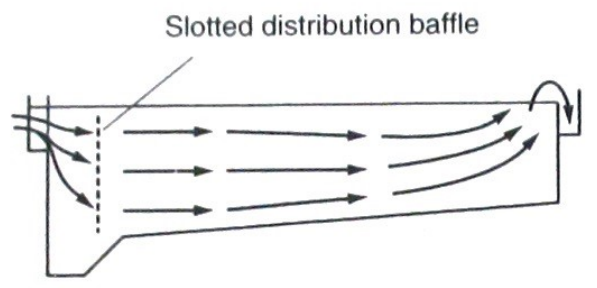

(a)

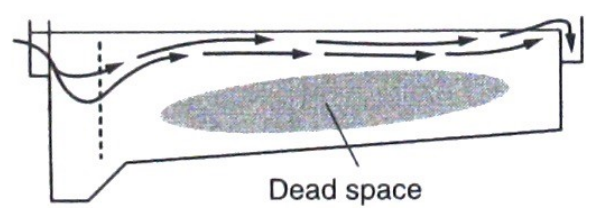

(c)

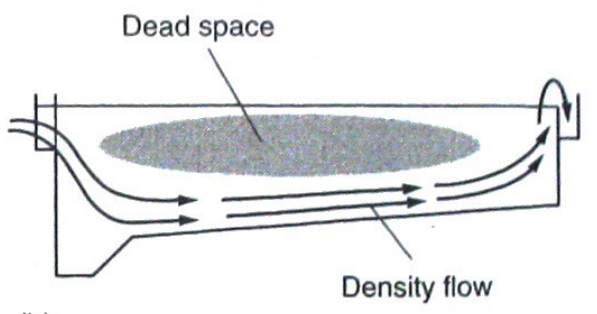

(b)

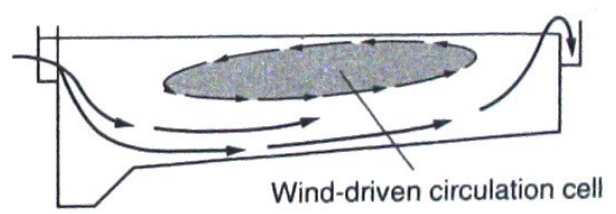

(d)

Figure 16. Flow patterns in rectangular sedimentation tanks: a) ideal flow; b) density flow where water in tank is warmer than influent; c) density flow where influent is warmer than water in tank; d) a wind-driven circulation cell. These various flow patterns can prevent the adequate sedimentation of suspended solids flocs and the pathogens associated with them. (reproduced with permission from Small and Decentralized Wastewater Management Systems, Crites and Tchobanoglous, 1988, copyright McGraw-Hill Education)

\subsection{Chemical Factors}

Chemical coagulants such as ferric chloride and aluminum sulfate (i.e., alum) increase the removal of TSS in conventional primary sedimentation from $50-70 \%$ to 80-90\% in CEPT/APT processes (Metcalf and Eddy/AECOM, 2014). As a result, more pathogens would be removed with CEPT/APT, especially helminth eggs (Jimenez et al., 2001; Chavez et al., 2004).

Table 2 presented a summary of the main factors and mechanisms associated with pathogen removal in primary sedimentation.

\subsection{Design, Operation, and Maintenance Guidelines for Pathogen Removal}

For conventional primary sedimentation there is little that can be done (besides designing for improved hydraulic performance as discussed in section 4.2) to enhance the removal of pathogens because sedimentation basins are designed to remove suspended organic matter. The design engineer must ensure that wastewater treatment systems using primary treatment also have downstream secondary treatment processes such as trickling filters or activated sludge that are followed by disinfection, to remove pathogens from the final effluent to the extent necessary for their safe reuse. Primary sludge is highly unstable and contains high concentrations of pathogens; therefore it must be stabilized and treated for pathogens before safe reuse or final disposal.

CEPT/APT processes can be designed for helminth removal based on laboratory and pilot scale studies of the raw wastewater (Jimenez et al., 2010; Jimenez, et al., 2001; Jimenez and Chavez, 2002; Jiménez-Cisneros and ChávezMejía, 1997), but require a downstream filtration stage to meet the WHO guidelines of $<1$ helminth egg/L and a disinfection stage for bacteria and protozoa (Jimenez et al., 2001). Again, sludge produced from CEPT/APT processes contains high concentrations of pathogens and must be stabilized and treated prior to reuse (Jimenez et al., 2000).

Table 3 presents a summary of key factors associated with the removal of the four major groups of indicator pathogenic organisms in conventional primary sedimentation and CEPT/APT processes. 
Table 3. Summary of key factors for indicator pathogen removal in primary sedimentation and CEPT/APT processes.

\section{Factor}

Hydraulic Overflow Rate

Basin Hydraulic Design

Coagulation/Flocculation

Continuous Sludge Removal

Hydraulic Overloading

Excessive Sludge Accumulation in

Settling Tank/Basin (associated with

poor maintenance)

Post-Treatment
Indicator/Pathogen removal is potentially $\uparrow$ enhanced or $\downarrow$ reduced under the following conditions:

Lower Overflow Rate $=\uparrow$ Pathogen Removal

Proper Configuration $=$ Minimized Solids Loss $=\uparrow$ Pathogen Removal

Correct Addition of Chemical and Dose $=\uparrow$ Pathogen Removal

Removal of Sludge $=\uparrow$ Pathogen Removal

Hydraulic Overloading $=\downarrow$ Pathogen Removal

Excessive Sludge Accumulation $=\downarrow$ Pathogen Removal

Primary sedimentation (with or without CEPT/APT) requires downstream treatment of effluent and treatment of sludges

\subsection{Data on Indicator and Pathogen Removal in Primary Sedimentation}

Figure 17 summarizes literature data on pathogen removal in conventional primary sedimentation and CEPT/ Jimenez et al., 2010; Jimenez et al., 2001).
APT processes. There are a paucity of data on pathogen removal from CEPT/APT processes at full-scale wastewater treatment plants and, as a result, the helminth data for CEPT/APT processes are based on laboratory and pilot scale studies (Jimenez-Cisneros and Chavez-Mejia, 1997; Jimenez and Chavez, 2002;

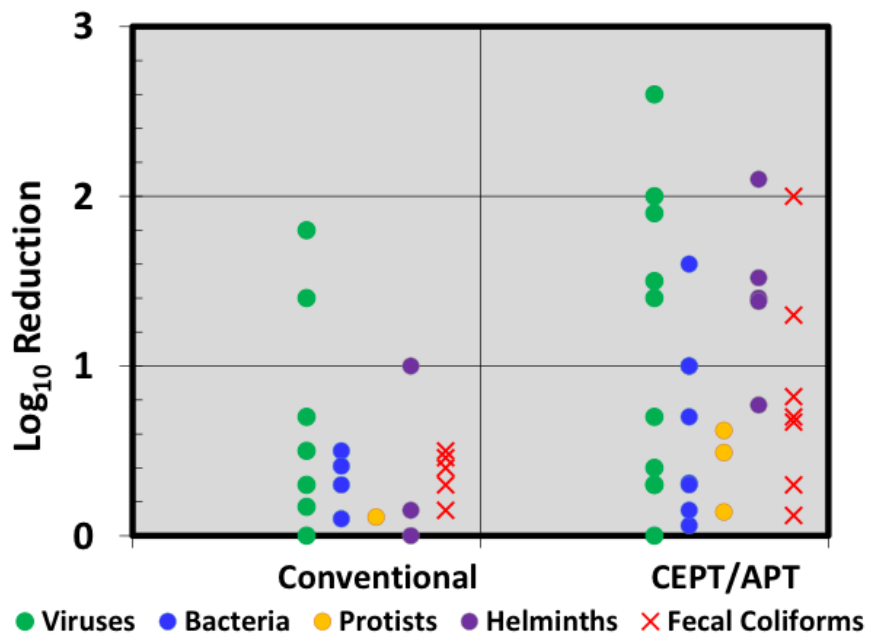

Figure 17. Reported $\log _{10}$ removal of pathogens and fecal coliforms (including E. coli) in conventional primary sedimentation and chemically enhanced/advanced primary treatment (CEPT/APT) processes. CEPT/APT data for helminths are from laboratory and pilot plant studies. Sources of data: Bosch et al., 1986; Chauret et al., 1999; Chavez et al., 2004; George et al., 2002; Jimenez-Cisneros and Chavez-Mejia, 1997; Jimenez and Chavez, 2002; Jimenez et al., 2010; Jimenez, et al., 2001; Lucena et al., 2004; Nordgren et al., 2009; Payment et al., 2001; Tanji et al., 2002; Zhang and Farahbakhsh, 2007

Table 4 presents a summary of the typical ranges and values of the removal of the four categories of pathogenic organisms and indicator organisms in conventional primary sedimentation and CEPT/APT processes. It is not expected that discrete pathogens and indicator organisms are removed by settling during conventional primary treatment. They are removed however when attached to particles. As shown in Table 3 and Figure 17, the reduction of viral, bacterial, and protozoan pathogens and fecal indicators can be expected to range from 0 to $1 \log _{10}$ units, and from 0 to $<1 \log _{10}$ for helminths, for conventional primary sedimentation (WHO, 2006). CEPT and APT processes, however, have been proposed for helminth egg removal and removals from 1 to $3 \log _{10}$ have been reported (WHO, 2006). Furthermore, removal rates from 1 to $2 \log _{10}$ for viruses, bacteria, and protozoa have also been reported in the literature for CEPT/APT (WHO, 2006). 
Table 4. Summary of indicator and pathogen removal $\left(\log _{10}\right)$ from wastewater in primary sedimentation and CEPT/APT.

\section{Typical pathogen and fecal indicator $\log 10$ removal values ${ }^{a}$ (typical ranges shown in parentheses)}

\begin{tabular}{|c|c|c|c|c|c|}
\hline Process & Bacterial Pathogens & Viruses & Protists & $\begin{array}{l}\text { Helminth } \\
\text { Eggs }\end{array}$ & $\begin{array}{c}\text { Fecal } \\
\text { Coliforms } \\
\text { (including } \\
\text { E. coli) } \\
\end{array}$ \\
\hline $\begin{array}{l}\text { Conventional } \\
\text { Primary } \\
\text { Sedimentation }\end{array}$ & $\begin{array}{c}0.1 \text { to } \\
0.41\end{array}$ & $\begin{array}{c}\text { negligible } \\
\text { to } 1.8\end{array}$ & 0.11 & 0.15 to 1.0 & $\begin{array}{c}0.15 \text { to } \\
0.5\end{array}$ \\
\hline $\begin{array}{l}\text { CEPT/APT } \\
\text { Processes }\end{array}$ & $\begin{array}{c}0.31 \text { to } \\
1.6\end{array}$ & $\begin{array}{c}\text { negligible } \\
\text { to } 2.6\end{array}$ & $\begin{array}{c}0.14 \text { to } \\
0.62\end{array}$ & 0.77 to 2.1 & $\begin{array}{c}0.12 \text { to } \\
2.0\end{array}$ \\
\hline
\end{tabular}

${ }^{a}$ Sources: Bosch et al., 1986; Chauret et al., 1999; Chavez et al., 2004; George et al., 2002; Jimenez-Cisneros and Chavez-Mejia, 1997; Jimenez and Chavez, 2002; Jimenez et al., 2010; Jimenez et al., 2001; Lucena et al., 2004; Nordgren et al., 2009; Payment et al., 2001; Tanji et al., 2002; Zhang and Farahbakhsh, 2007.

\subsection{Data on Pathogens in Sludge from Primary Treatment}

Primary treatment produces sludge at a rate of 110 $170 \mathrm{~kg}$ dry solids $/ 1,000 \mathrm{~m}^{3}$ of domestic wastewater treated, and this sludge must be stabilized, dewatered and preferably disinfected prior to reuse or final disposal (Chernicharo, 2007). Primary sludge contains high concentrations of pathogens, even if it has been stabilized and dewatered, as shown in Table 5.

Table 5. Concentrations of pathogens found in primary sludge ${ }^{1}$ (Jimenez et al., 2002).

\begin{tabular}{lcc}
\hline \multicolumn{1}{c}{ Pathogen } & Country/Region & Number per gram total solid \\
\hline Viruses & Mexico & $1 \mathrm{E}+03$ to $1 \mathrm{E}+06 \mathrm{PFU}$ \\
Coliphages & $\mathrm{USA}$ & $1.3 \mathrm{E}+06 \mathrm{PFU}$ \\
Bacteria & & \\
Salmonella typhi & Mexico & $1 \mathrm{E}+06$ to $1 \mathrm{E}+08 \mathrm{MPN}$ \\
& $\mathrm{USA}$ & $1 \mathrm{E}+03 \mathrm{MPN}$ \\
Fecal coliforms & Mexico & $1 \mathrm{E}+07$ to $1 \mathrm{E}+10 \mathrm{MPN}$ \\
& USA & $1 \mathrm{E}+07 \mathrm{MPN}$ \\
Protozoa & & \\
Giardia lamblia & Mexico & $1 \mathrm{E}+02$ to $1 \mathrm{E}+04 \mathrm{cysts}$ \\
Helminths eggs & USA & $1 \mathrm{E}+02$ cysts \\
& Mexico & 73 to 177 viable eggs \\
& USA & $<1$ to 10 viable eggs \\
& Brazil & 75 eggs \\
& Egypt & 67 eggs \\
& Ghana & 76 eggs \\
& France & 5 to 7 eggs \\
& Germany & $<1$ eggs \\
& United Kingdom & $<6$ eggs
\end{tabular}

\footnotetext{
${ }^{1}$ Some of the data are from stabilized and dewatered sludges; ${ }^{2}$ PFU-plaque forming units; MPN-most probable number.
} 


\section{References}

Andreoli, C.V., von Sperling, M., Fernandes, F. and Ronteltap, M. (2007). Sludge treatment and disposal. IWA Publishing. London, United Kingdom.

Bosch, A., Lucena, F. and Jofre, J. (1986). Fate of Human Enteric Viruses (Rotaviruses and Entero Viruses) in Sewage after Primary Sedimentation. Water Science and Technology. 18, pp. 47-52.

Chávez, A., Jiménez, B. and Maya, C. (2004). Particle size distribution as a useful tool for microbial detection. Water Science and Technology. 50, pp. 179-186.

Chauret, C., Springthorpe, S. and Sattar, S. (1999). Fate of Cryptosporidium oocysts, Giardia cysts, and microbial indicators during wastewater treatment and anaerobic sludge digestion. Canadian Journal of Microbiology. 45, pp. 257-262.

Chernicharo, C. (2007). Anaerobic Reactors. Biological wastewater treatment Series. 4, IWA Publishing, UK.

Cizek, A.R., Characklis, G.W., Krometis, L.A., Hayes, J.A., Simmons, O.D., Di Lonardo, S. et al. (2008). Comparing the partitioning behavior of Giardia and Cryptosporidium with that of indicator organisms in stormwater runoff. Water Research. 42, pp. 4421-4438.

Clay, S., Hodgkinson, A., Upton, J. and Green, M. (1996). Developing acceptable sewage screening practices. Water Science and Technology. 33, pp. 229-234.

David, E.D. and Lindquist, W.D. (1982). Determination of the specific gravity of certain helminth eggs using sucrose density gradient centrifugation. The Journal of Parasitology. JSTOR. pp. 916-919.

EPA, US (2003). Wastewater Technology Fact Sheet. Screening and Grit Removal.

Feachem, R.G., Bradley, D.J., Garelick, H. and Mara, D.D. (1981). Appropriate Technology for Water Supply and Sanitation: Health Aspects of Excreta and Sullage Management- A State-of-the-Art Review. World Bank.

Feachem, R.G., Mara, D.D. and Bradley, D.J. (1983). Sanitation and disease. John Wiley and Sons Washington DC, USA.

George, I., Crop, P. and Servais, P. (2002). Fecal coliform removal in wastewater treatment plants studied by plate counts and enzymatic methods. Water Research. 36, pp. 2607-2617.

Heinonen-Tanski, H., Reponen, T. and Koivunen, J. (2009). Airborne enteric coliphages and bacteria in sewage treatment plants. Water Research. 43, pp. 2558-2566.

Heinonen-Tanski, H., Reponen, T. and Koivunen, J. (2009). Airborne enteric coliphages and bacteria in sewage treatment plants. Water Research. 43(9), pp. 2558-2566.

Jiménez-Cisneros, B. and Chávez-Mejía, A. (1997). Treatment of Mexico City wastewater for irrigation purposes. 
Environmental Technology. 18, pp. 721-729.

Jiménez-Cisneros, B.E., Maya-Rendon, C. and Salgado-Velázquez, G. (2001). The elimination of helminth ova, faecal coliforms, Salmonella and protozoan cysts by various physicochemical processes in wastewater and sludge. Water Science and Technology. 43, pp. 179-182.

Jiménez, B., Barrios, J.A. and Maya, C. (2000). Class B biosolids production from wastewater sludge with high pathogenic content generated in an advanced primary treatment. Water Science and Technology. 42, pp. 103-110.

Jiménez, B. and Chávez, A. (2002). Low cost technology for reliable use of Mexico City's wastewater for agricultural irrigation. Technology. 9, Cognizant Communication Corporation. pp. 95-107.

Jiménez, B., Mara, D., Carr, R. and Brissaud, F. (2010). Wastewater treatment for pathogen removal and nutrient conservation: suitable systems for use in developing countries. Astewater Irrigation. pp. 149.

Kulkarni, P., Dutari, G., Biswas, P. and Haught, R. (2004). Gravity settling characteristics of Cryptosporidium parvum oocysts in aqueous suspension using in situ static light scattering. Colloids and Surfaces A: Physicochemical and Engineering Aspects. 233, pp. 1-10.

Li, J., Zhou, L., Zhang, X., Xu, C., Dong, L. and Yao, M. (2016). Bioaerosol emissions and detection of airborne antibiotic resistance genes from a wastewater treatment plant. Atmospheric Environment. 124, pp. 404-412.

Lucena, F., Duran, A.E., Morón, A., Calderón, E., Campos, C., Gantzer, C. et al. (2004). Reduction of bacterial indicators and bacteriophages infecting faecal bacteria in primary and secondary wastewater treatments. Journal of Applied Microbiology. 97, pp. 1069-1076.

Marín, I., Goñi, P., Lasheras, A.M. and Ormad, M.P. (2015). Efficiency of a Spanish wastewater treatment plant for removal potentially pathogens: Characterization of bacteria and protozoa along water and sludge treatment lines. Ecological Engineering. 74, pp. 28-32.

Mara, D. (2013). Domestic wastewater treatment in developing countries. Routledge.

Medema, G.J., Schets, F.M., Teunis, P.F.M. and Havelaar, A.H. (1998). Sedimentation of Free and AttachedCryptosporidium Oocysts and Giardia Cysts in Water. Applied and Environmental Microbiology. 64, pp. 4460-4466.

Metcalf and Eddy Ltd (2014). Wastewater Engineering: Treatment and Resource Recovery, 5th ed. McGraw-Hill, New York, NY, USA.

Mohammed, A.O., Tchobanoglous, G., Stensel, H.D., Tsuchihashi, R. and Burton, A.F. (2014). Wastewater Engineering: Treatment and Resource Recovery. 5th edition McGraw-Hill. New York, USA.

Nordgren, J., Matussek, A., Mattsson, A., Svensson, L. and Lindgren, P.E. (2009). Prevalence of norovirus and factors influencing virus concentrations during one year in a full-scale wastewater treatment plant. Water Research. 43, pp. 1117-1125. 
Payment, P., Plante, R. and Cejka, P. (2001). Removal of indicator bacteria, human enteric viruses, Giardia cysts, and Cryptosporidium oocysts at a large wastewater primary treatment facility. Canadian Journal of Microbiology. 47, pp. 188-193.

Sengupta, M.E., Thamsborg, S.M., Andersen, T.J., Olsen, A. and Dalsgaard, A. (2011). Sedimentation of helminth eggs in water. Water Research. 45, pp. 4651-4660.

Shannon, K.E., Lee, D.Y., Trevors, J.T. and Beaudette, L.A. (2007). Application of real-time quantitative PCR for the detection of selected bacterial pathogens during municipal wastewater treatment. Science of the Total Environment. 382, pp. 121-129.

Szostkova, M., Vitez, T., Marecek, J. and Losak, T. (2012). Microbial contamination of screenings from wastewater treatment plants. Polish Journal of Environmental Studies.

Tilley, E. (2014). Compendium of Sanitation Systems and Technologies [Electronic resource]. Swiss Federal Institute of Aquatic Science and Technology (Eawag). Dübendorf, Switzerland.

WHO (2006). Guidelines for the safe use of wastewater, excreta and greywater. Volumes I-IV. World Health Organization.

Yasunori, T., Katsunori, M., Masatoshi, Y., Masatomo, M., Katsutoshi, H. and Hajime, U. (2002). Fate of coliphage in a wastewater treatment process. Journal of Bioscience and Bioengineering. 94, pp. 172-174.

Zhang, K. and Farahbakhsh, K. (2007). Removal of native coliphages and coliform bacteria from municipal wastewater by various wastewater treatment processes: implications to water reuse. Water Research. 41, pp. 2816-2824. 